\title{
Revision of the genus Blauta LeConte (Coleoptera, Elateridae, Elaterinae, Ampedini, Dicrepidiina)
}

\author{
Sônia A. Casari ${ }^{1,2}$
}

${ }^{1}$ Museu de Zoologia, Universidade de São Paulo. Caixa Postal 42494, 04218-970 São Paulo-SP, Brazil. casari@usp.br ${ }^{2} \mathrm{CNPq}$ fellowship.

\begin{abstract}
Revision of the genus Blauta Leconte (Coleoptera, Elateridae, Elaterinae, Ampedini, Dicrepidiina). The genus Blauta Leconte, 1853 is formed by two species, B. cribraria (Germar, 1844) and B. falli Brown, 1936, recorded from Southeast of United States. The generic characterization and the redescriptions and morphological illustrations, including mouthparts and genitalia, of both species are presented. A comparison of both species is also included.
\end{abstract}

KEYWORDS. Blauta, Dicrepidiina, genitalia, mouthparts, taxonomy.

RESUMO. Revisão do gênero Blauta Leconte (Coleoptera, Elateridae, Elaterinae, Ampedini, Dicrepidiina). O gênero Blauta Leconte, 1853 está formado por duas espécies, B. cribraria (Germar, 1844) e B. falli Brown, 1936, registradas no Sudeste dos Estados Unidos. A caracterização do gênero e as redescrições e ilustrações da morfologia, incluindo peças bucais e genitália, das duas espécies são apresentadas. A comparação entre as duas espécies também está incluída.

PALAVRAS-CHAVE. Blauta, Dicrepidiina, genitália, peças bucais, taxonomia.

The genus Blauta, established by LeConte (1853) to include $B$. cauta, was based on one specimen from Georgia. This author stated about his disposition in considering this specimen as Ampedus cribrarius Germar, 1844, but the presence of the thorax a little longer than wide and the antennae very distinctly serrate, led him to describe a new species and erect a new genus, in his sistem of classification, placed after Elater.

Candèze (1859) included Blauta in "Elatérites" and presented a key to genera. This genus was characterized by tarsi spongy ventrally, with short lamella under the protarsomeres. According to him, the presence of lamellate tarsi put this genus very near to the "Dicrépidiites", especially to Heterocrepidius, but after hesitating about the correct position, it was included after Elater, distant from the "Dicrépidiites". He emphasized that the genus Blauta is an intermediary between Heterocrepidius and Elater. He also transferred Ampedus cribrarius Germar, 1844 to Blauta and synonymized B. cauta Leconte, 1853 under $B$. cribrarius. This position was followed in 1891 .

Schenkling (1925) catalogued Blauta, monotypical, in the subfamily Elaterinae.

Brown (1936) described Blauta falli from Miami, Florida and stated about the difficulties in distinguishing the lamellae of tarsomeres, especially in B. cribraria.

Stibick (1979) included Blauta in Dicrepidiini.

Here, a diagnosis to the genus and the redescriptions and illustrations of both species are presented. The material studied belongs to Florida State Collection of Arthropods, Gainesville (FSCA) and Museu de Zoologia, Universidade de São Paulo (MZSP).

\section{Blauta Leconte, 1853}

Blauta LeConte, 1853: 472; Candèze, 1859: 416, 489; 1891: 94; Schwarz, 1906: 110, 121; Schenkling, 1925: 163; Brown, 1936: 251

Type-species: Ampedus cribrarius Germar, 1844, by monotypy.

Subcylindrical. Frons convex, anterior margin rounded and carinate; nasal high and punctuate. Antennae (Figs. 1, 26) serrate from $4^{\text {th }}$ antennomere; $2^{\text {nd }}$ globular, $3^{\text {rd }}$ intermediary; last strongly narrow near apex; in male, surpassing hind angles of pronotum in a half antennomere. Epipharynx (Fig. 28) membranous and densely clothed with yellowish setae, longer near apex; two basal sclerites with sensoria; several sensoria dispersed near middle. Mandibles (Figs. 5-7, 30-33) symmetrical, with a dorsal carina near middle; setous dorsolaterally; penicillus formed by fringe of short setae. Maxillae (Figs. 4, 29): basiestipes subrectangular and setous; medioestipes elongate, subtriangular with longitudinal carina and fringe of setae parallel external margin and shorte setae near base; palpifer with setae near base; palpi setous, with 4 palpomeres; palpomere distal slightly widened at apex; galea and lacinia brush-like. Mentum slightly wider than long. Pronotum (Figs. 45,46 ) with lateral sutures incomplete anteriorly and not visible from above at anterior half; anterior margin almost straight; posterior margin notched at middle; hind angles slightly divergent and carinate at middle; antebasal region slightly grooved. Pronotosternal sutures (Figs. 9, 35) slightly arched, opened frontally forming an anterior channel, marginate by narrow smooth band. Prosternum slightly convex, dense- and 

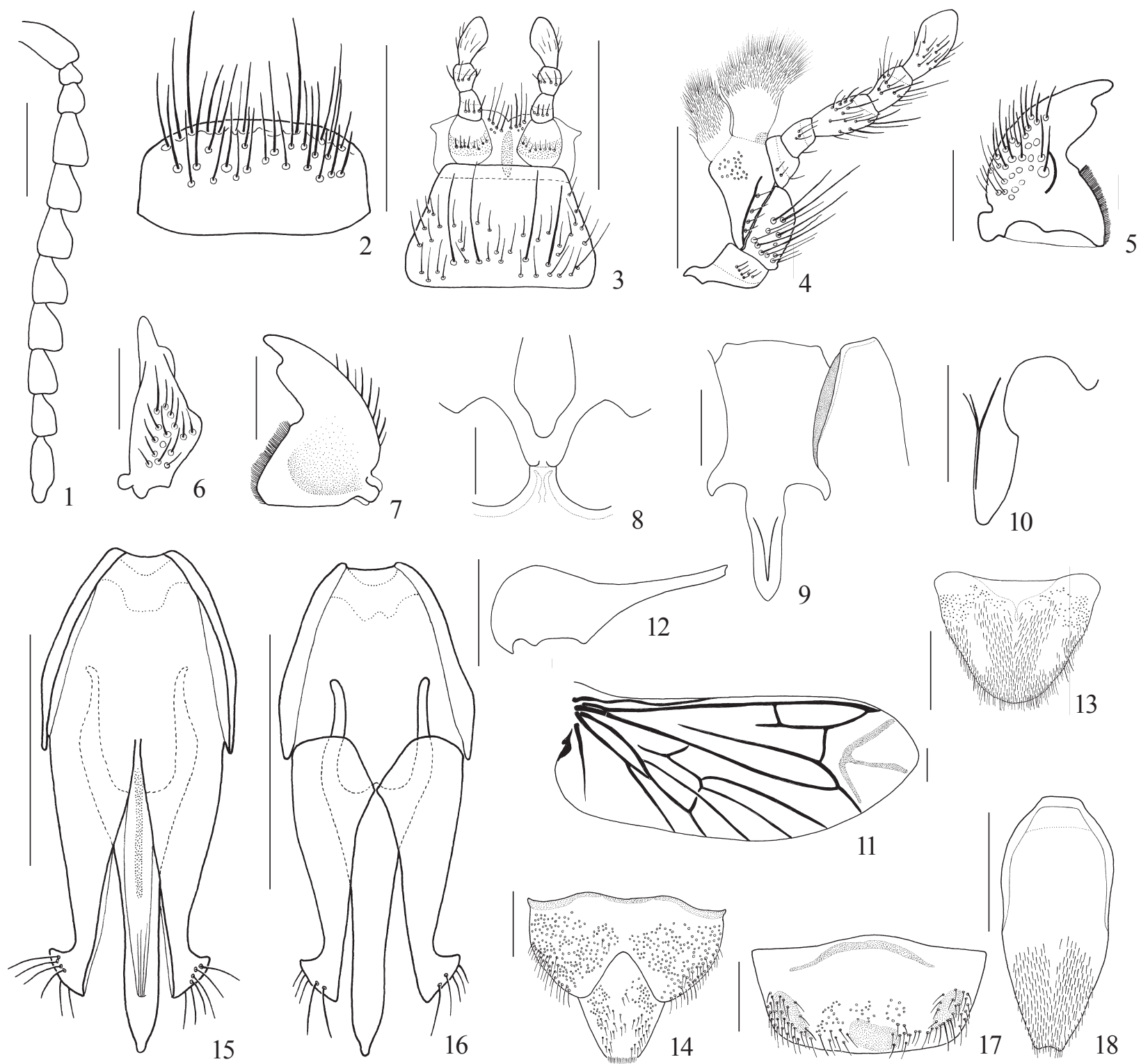

9
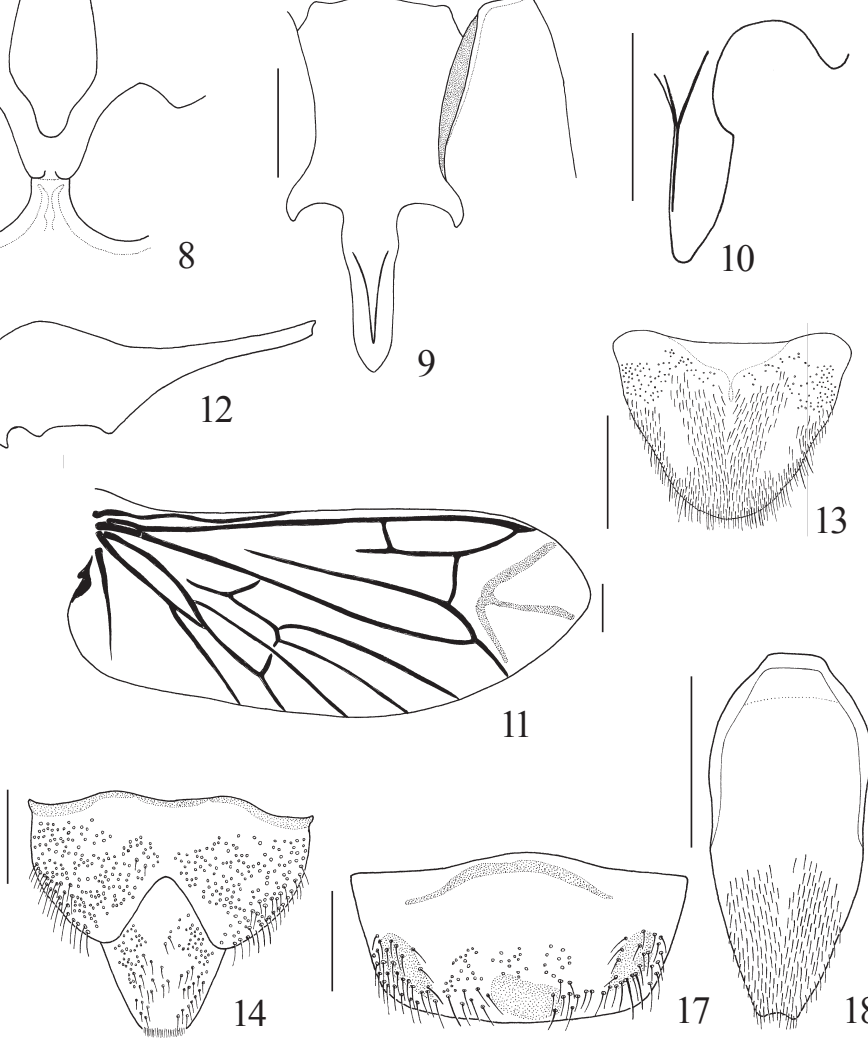

5

Figs. 1-18. Blauta cribraria (Germar, 1844), male. 1, antenna; 2, labrum; 3, labium; 4, maxilla; 5-7, mandible (dorsal, lateroexternal, ventral); 8, mesosternal cavity (ventral); 9, prosternum and anterior part of hypomeron; 10, prosternal spine (lateral); 11, hind wing; 12, metacoxal plate; 13, tergite $8 ; 14$, tergites $9-10 ; 15,16$, aedeagus (ventral, dorsal); 17 , sternite $8 ; 19$, sternite 9 . Bars $=5 \mathrm{~mm}$ except figs. $1,9-12,15,16,18=1 \mathrm{~mm}$.

coarsely punctate, narrowed between procoxae; prosternal lobe with anterior margin almost straight. Mesosternal cavity (Figs. 8, 36, 37) narrow between mesocoxae, with borders declivous slightly notched at middle. Metacoxal plates (Figs. $12,38)$ strongly narrowed at lateral half. Tibial spurs present; tarsomeres 1-4 (Figs. 47-49) lamellate beneath. Hind wing (Fig. 11): wedge cell present and apical sclerotization three branched. Tergite 8 of male (Figs. 13, 39) wider than long, subtriangular, with distal margin rounded; translucent in a narrow basal area, partially clothed with moderately long setae. Sternite 8 of male (Figs. 1, 43) band-like, translucent with a narrow and transverse sclerotized band, near base and 3 rounded and irregular near anterior margin; setae moderately long near anterior margin, interrupted at middle. Sternite 9 of male (Figs. 18, 44) elongate, narrow, with moderately long setae on distal third. Tergite 9 of male (Figs. 14, 40) transverse, strongly notched medioanterioly; densely punctate with short setae near lateral margins. Tergite 10 of male (Figs. 14, 40) elongate, fitted at apex of tergite 9, slightly narrowed apicad, punctate near base, with short setae on distal 2/3. Aedeagus (Figs. 15, 16, 41, 42): parameres fused ventrally by basal membrane, with cuneiform apex and several moderately long setae near apex; median lobe surpassing parameres apices, with constricted apex.

\section{Blauta cribraria (Germar, 1844)}

(Figs. 1-25, 45, 47)

Ampedus cribrarius Germar, 1844: 178.

Blauta cribraria; Candèze, 1859: 490; Schenkling, 1925: 163. 


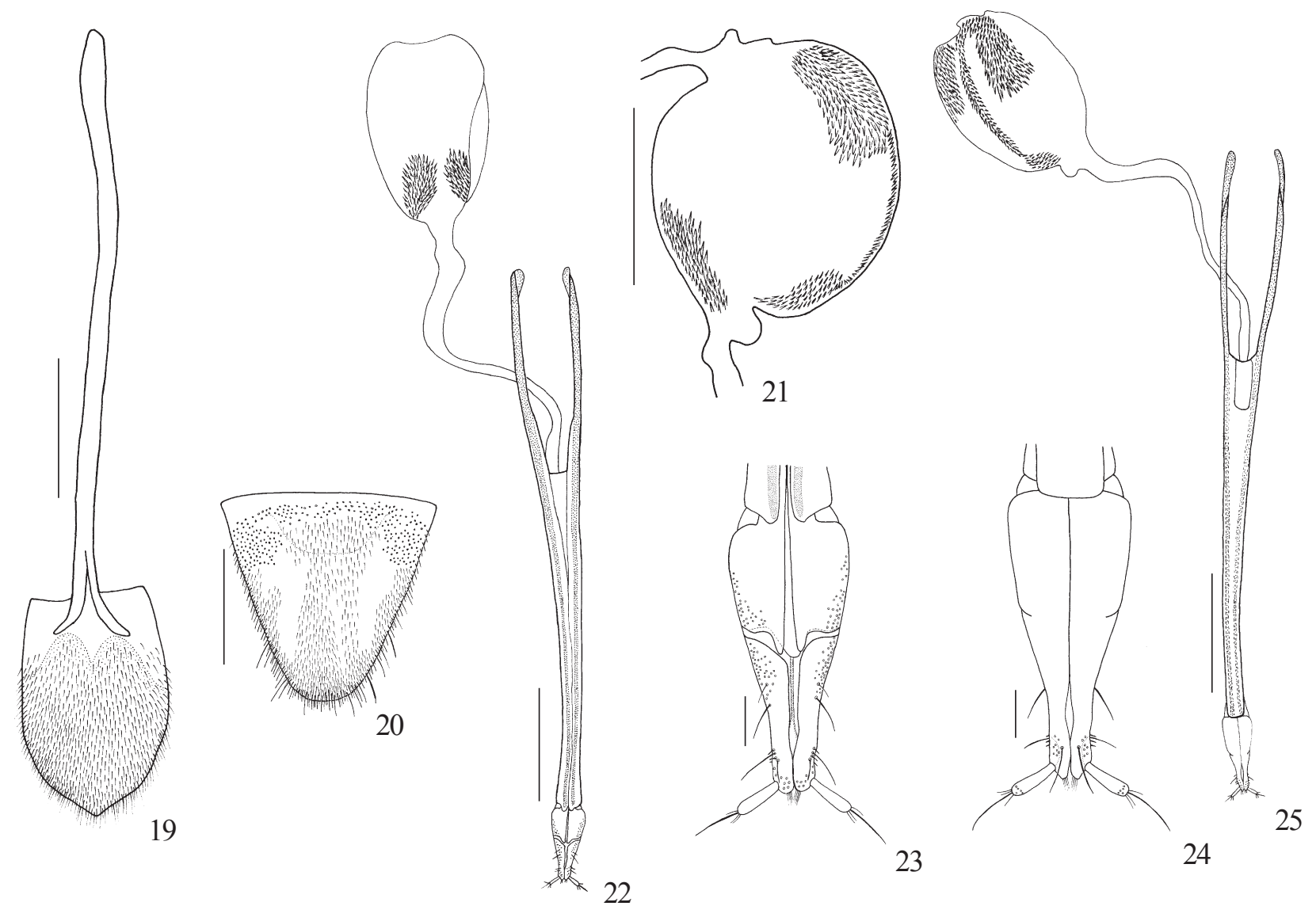

Figs. 19-25. Blauta cribraria (Germar, 1844), female. 19, sternite $8 ; 20$, tergite $8 ; 21$, bursa copulatrix (lateral); 22, 25, genitalia (ventral, dorsal); 23, 24, apex of ovipositor (ventral, dorsal). Bars $=1 \mathrm{~mm}$ except figs. $23,24=0.1 \mathrm{~mm}$.

Aphanobius cribrarius Dej. Cat. p. 104; Candèze, 1859: 490 (syn.). Blauta cauta LeConte, 1853: 473; Candèze, 1859: 490 (syn.).

Length: 9-16 mm. Reddish-brown, usually with antennae and legs lighter. Pubescence moderately long, bristle, dense and golden, shorter and denser on antennae. Frons (Fig. 45) convex with punctation moderately coarse and dense. Antennae (Fig. 1): in female, not reaching hind angles of pronotum; $4^{\text {th }}$ antennomere longer than wide. Labrum (Fig. 2) transverse, strongly convex, with anterior margin rounded; long setae on anterior half. Mandibles (Figs. 5-7): with a rounded tooth near apex; moderately raised dorsally. Maxillae (Fig. 4): basistipes bearing long setae; mediostipes bearing a row of moderately long setae externally to carina. Labium (Fig. 3): prementum membranous, ligula widened at apex, with anterior margin slightly notched at middle, bearing moderately long setae near middle; palpiger bearing short setae; mentum bearing setae of varied sizes on basal 2/3. Pronotum (Fig. 45) almost as long as wide, strongly convex, narrowed near apex; punctation moderately coarse and dense; lateral margins not visible from above; median basal tubercle transverse and flattened. Hypomera narrow with punctation slightly smaller than pronotum. Prosternal spine (Figs. 9-10) almost straight with a longitudinal median carina; apex narrow and acuminate. Metacoxal plate (Fig. 12) with a tooth near middle. Scutellum
(Fig. 45) subpentagonal and declivous. Elytra strongly convex, parallel on anterior half, narrowed at $1 / 4$ distal and widened at $1 / 4$ anterior to distal; striae punctate; interstices equal, flat and punctate.

Male. Aedeagus (Figs. 15, 16): basal piece long, 0.77 times parameres (dorsal view) length; median lobe narrow.

Female.Tergite 8 (Fig. 20) almost as wide as long, slighly narrow apicad, partially clothed with short setae. Sternite 8 (Fig. 19) longer than wide; distal margin rounded and prominent at middle; densely clothed with short setae, except near base; basal sclerite 3.25 times sternite length. Ovipositor (Figs. 22, 25) long; coxites (Figs. 22-25) short, ventrally giving the appearance of 2-segmented; laterodistal stylus, setous near apex.

Material examined. UNITED STATES OF AMERICA. North Carolina: Moore Co., Southern Pines, 1 M (FSCA). South Carolina: Anderson and Pickens Cos., Clemson College, 1 M (MZSP). Mississipi: Forrest Co., Hattiesburg, 2 M (FSCA), Camp Shelby, nr. Hattiesburg, 1 M (MZSP). Alabama: Mobile Co., Mobile, 3 M, 1 F (FSCA). Georgia: Lowndes Co., 3 M (FSCA), 1 M (MZSP). Florida: Alachua Co., $1 \mathrm{M}$ (FSCA), Gainesville, 3 M (FSCA), Pine Hills Estates, Gainesville, $1 \mathrm{M}$ (FSCA); Columbia Co., Lake City, 1 M (FSCA); Escambia Co., Pensacola, 1 M, 1 F (FSCA); Indian River Co., 1 M (FSCA); Leon Co., Tall Timbers, 1 M (FSCA); Marion Co., Ocala, 1 F (FSCA); Osceola Co., 1 M (FSCA); Putman Co., Weems Property, Red Water Lake, 1 M (FSCA). 


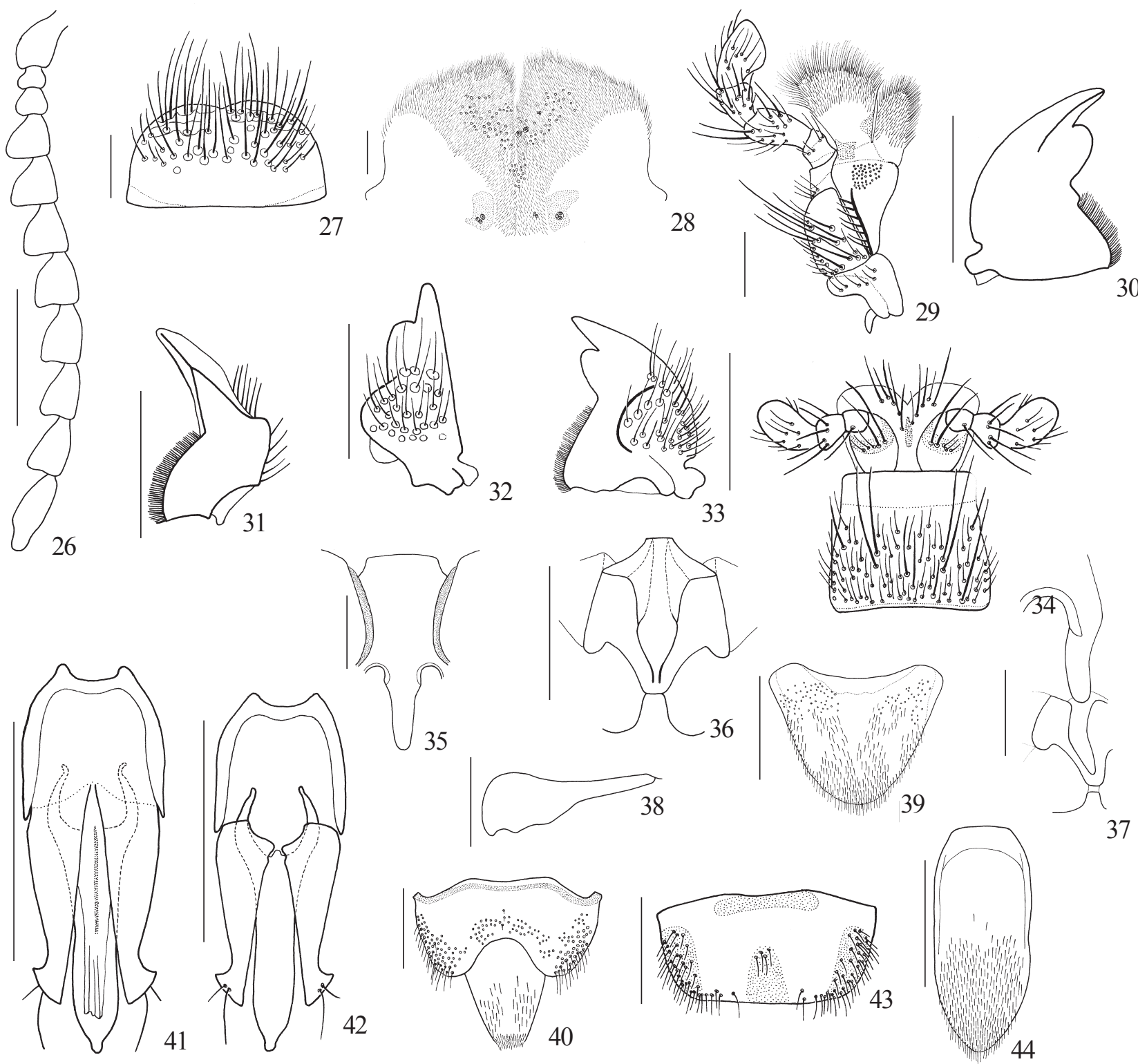

Figs. 26-44. Blauta falli Brown, 1936, male. 26, antenna; 27, labrum; 28, epipharynx; 29, maxilla; 30-33, mandible (ventral, laterointernal, lateroexternal, dorsal); 34, labium; 35, prosternum; 36, mesosternal cavity (ventral); 37, prosternal spine and mesosternal cavity (lateroventral); 38 , metacoxal plate; 39 , tergite $8 ; 40$, tergites $9-10 ; 41,42$, aedeagus (ventral, dorsal); 43, sternite $8 ; 44$, sternite 9 . Bars $=1 \mathrm{~mm}$, except figs. $27,29,34=2 \mathrm{~mm}$ and $30-33,39,40,43,44=5 \mathrm{~mm}$.

Blauta falli Brown, 1936

(Figs. 26-44, 46, 48, 49)

Blauta falli Brown, 1936: 251

Length: 9.0-11.5 mm. Black totally or with antennae, legs and ventrites dark- or reddish-brown. Pubescence short, bristle and golden, denser on antennae. Frons (Fig. 46) convex, dense, coarse and irregularly punctate. Antennae (Fig. 26): $4^{\text {th }}$ antennomere almost as wide as long. Labrum (Fig. 27) transverse, strongly convex, with anterior margin bilobed; setae long and sparse inserted in coarse punctation on anterior 2/3. Mandibles (Figs. 30-33): with a rounded subapical tooth; strongly raised dorsally, very robust lateroexternally (Fig. 32).
Maxillae (Fig. 29): mediostipe with a row of moderately long setae on carina. Labium (Fig. 34): ligula widened apicad, with anterior margin notched at middle, with long setae near middle; palpiger bearing long and short setae; mentum bearing setae of moderately size on basal 2/3. Pronotum (Fig. 46) longer than wide, slightly narrowed anteriorly; strongly convex, with punctation very dense, irregular and moderately; median basal tubercle indistinguishable in the majority of specimens. Hypomera narrow with punctation coarser and sparser than pronotum. Prosternal spine (Figs. 35, 37) cylindrical, curved with rounded apex. Metacoxal plate (Fig. 38) with margin slightly sinuous at internal half. Scutellum (Fig. 46) elongate, declivous, with posterior margin rounded. Elytra parallel on anterior $2 / 3$ and slightly narrowed apicad; apices conjointly 


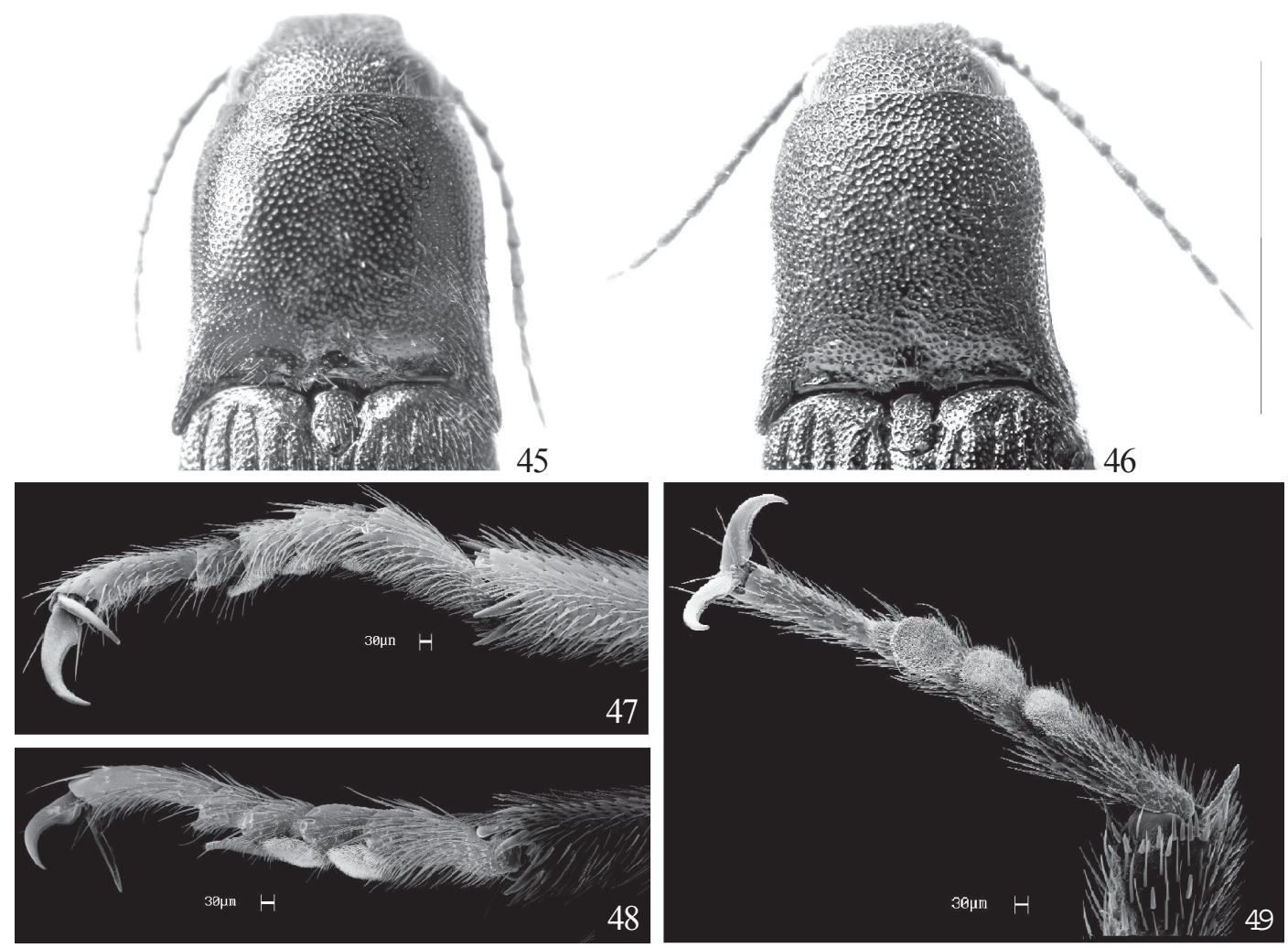

Figs. 45-49. Head, pronotum and anterior region of mesonotum: 45, Blauta cribraria (Germar, 1844); 46, B. falli Brown, 1936. Protarsus: 47, B. cribraria (Germar, 1844) (lateral); 48, 49, B. falli Brown, 1936 (lateral, ventral). Bars $=60 \mu \mathrm{m}$.

rounded; interstices equal, convex and dense, irregularly and moderadely coarse punctate.

Male. Aedeagus (Figs. 41, 42): basal piece long, 0.80 times parameres (dorsal view) length; median lobe wide.

Material examined. UNITED STATES OF AMERICA. Florida: Broward Co., 1 M (FSCA), Deerfield, 1 M (FSCA); Dade Co., Homestead, 1 M (FSCA)(dissected), Perrine, 5 M (FSCA); Hernando Co., Withlacoochee State Forest, 1 M (FSCA); Hillsborough Co., Tampa, 1 M (FSCA); Indian River Co., South of Vero Beach, 1 M (FSCA); Marion Co., Juniper Springs, 2 M (FSCA).

\section{REMARKS}

The genus Blauta is recorded from southeast of United States, with B. falli restricted to Florida and B. cribraria, distributed in North Carolina, South Carolina, Mississipi, Alabama, Georgia and Florida.

The two species are easily separated by integument coloration, reddish-brown in B. cribraria and black in B. falli, and by pronotal punctation, coarser and denser in the latter. Besides, it was observed the following differences: pubescence shorter, mandibles stouter lateroexternally and with subapical tooth more developed and rounded and prosternal spine curve in $B$. falli, prosternal spine with longitudinal ventral carina, metacoxal plate with a tooth and scutellum pentagonal in $B$. cribraria. The anterior margin of labrum is rounded in $B$. cribraria and bilobed in B. falli. Comparing the male genital segments and aedeagus, they present small differences specially at anterior margin of tergite 9 , the shape and size of the darker areas sternite 8 and the width of median lobe of aedeagus.

Acknowledgement. To M. C. Thomas (FSCA) for sending the material as loan.

\section{REFERENCES}

Brown, W. J. 1936. Notes on some species of Elateridae (Coleoptera). The Canadian Entomologist 68: 246-252, 4 figs.

Candèze, E. 1859. Monographie des Élatérides. Mémoires de la Societé Royale de Sciences de Liège 14: 1-543, 7 pls.

Candèze, E. 1891. Catalogue Méthodique des élatérides connus en 1890. Liège, $H$. Vaillant-Carmanne. $246 \mathrm{p}$.

Germar, E. F. 1944. Bemerkungen über Elateriden vom Herausgeber. Zeitschrift für Entomologie 5: 133-192.

LeConte, J. L. 1853. Revision of the Elateridae of the United States. Transactions of the American Philosophical Society 10: $363-$ 403.

Stibick, J. N. L. 1979. Classification of the Elateridae (Coleoptera). Relationships and classification of the subfamilies and tribes. Pacific Insects 20: 145-186.

Schwarz, O. C. E. 1906. Coleoptera Fam. Elateridae. Fasc. 46A. In: P. Wystman (ed.). Genera Insectorum. Bruxelles, P. Wystman. $112 \mathrm{p}$.

Schenkling, S. 1925. Elateridae I. Pars 80. In: Coleopterorum Catalogus auspiciis et auxilio W. Junk. Berlin, W. Junk. 263 p.

Recebido em 06.I.2005; aceito em 15.VIII.2005 